Article

\title{
Evaluating Corporate Performance and Bank Productivity in China: The Moderating Role of Independent Directors
}

\author{
Israr Khan (1) and Mansi Wang * \\ School of Management, Guangzhou University, Guangzhou 510006, China; israrjee333@e.gzhu.edu.cn \\ * Correspondence: wangmansi@163.com; Tel.: +86-13342886761
}

Citation: Khan, I.; Wang, M. Evaluating Corporate Performance and Bank Productivity in China: The Moderating Role of Independent Directors. Sustainability 2021, 13, 3193. https://doi.org/10.3390/ su13063193

Academic Editors: Giuliana Birindelli and Haywantee Ramkissoon

Received: 6 February 2021

Accepted: 9 March 2021

Published: 15 March 2021

Publisher's Note: MDPI stays neutral with regard to jurisdictional claims in published maps and institutional affiliations.

Copyright: (C) 2021 by the authors. Licensee MDPI, Basel, Switzerland. This article is an open access article distributed under the terms and conditions of the Creative Commons Attribution (CC BY) license (https:/ / creativecommons.org/licenses/by/ $4.0 /)$.

\begin{abstract}
Corporate governance (CG) is not an abstract goal. It exists to serve the bank's purpose by giving a framework through which investors, directors, and the top management can efficiently follow its objectives. Subsequently, it boosts the financial performance of the bank for its shareholders. This paper explores CG and its impacts on financial performance from the evidence collected from selected commercial banks (CB) in China. The data sample for this research comprises selected CBs in China for the period from 2008 to 2019. Applying selection standards provides us a data sample of 17 CBs. We employed the generalized method of moments (GMM) regression model constructed on 170 observations to identify the variables' relationship. Our findings show that female independent directors positively and significantly affect bank financial performance. Despite the literature review, we found that the existence of female directors alone does not positively and significantly improve banks' financial performance. The finding suggests that female directors are more efficient when they are selected as independent directors. The findings show that CEO duality affects bank financial performance positively and significantly. CEO duality strengthens the financial performance of CBs because of the solidarity of the order it presents. The results also show that CEO shareholding and financial performance of Chinese CBs have a positively significant bond with each other. This result suggests that a blend of CG instruments is more impressive than one CG component. The investigation results added a new dimension to the governance literature that could be an important source of knowledge for policymakers and regulators to improve the current governance structure for better performance across countries. This paper support principal-agent theory and the author also provide some help for the theories that regulators should support gender quotas in the board of directors of banks to decrease risk-taking behavior.
\end{abstract}

Keywords: board gender diversity; CEO duality; ownership; moderating variable; financial performance

\section{Introduction}

Board gender diversity has become a significant variable in corporate governance (CG) in the changing economy. In the UK, gender diversity was brought up for the first-time in the amended CG code of 2012. This amendment was brought after considering different suggestions from Potter and Ramly [1,2]. CEO attributes like gender, education, and age significantly impact decision-making and organization performance [3]. In some economies, the appointment of female executives is compulsory. For example, the Norwegian and Spanish governments forced an obligatory quota for each scheduled bank to have at least $40 \%$ female executives. When we inspect the demographic distributions of Chinese banks' staff members, we find that many female employees are hired in Chinese commercial banks (CBs).

According to Chinese CBs in 2019, women staff members account for almost $50 \%$ of the total number of staff members. The reality that top management possesses female leaders should be observable when compared with female employees. Female staff members are under-represented in top positions. The findings show that business group association impairs the positive organization value of board demographic diversity [4]. The banking 
sector plays a significant role in financial and societal advancement in China. Our focus is on whether the CBs in China with more gender-diverse boards have preferable performance over the banks without female executives. Does the duality of a CEO-when one individual performs both the duties of bank $\mathrm{CEO}$ and chairperson-add to or reduce bank performance? This question is most significant, disputable, and uncertain in CG investigation and practice [5]. Agency theory perspectives conflict with the stewardship theory. Agency theory proposes that separate CEO and chair positions encourage more efficient observation and control of the CEO. Those organizations that neglect the separation of CEO and chairperson position maybe underperforming [6]. Organizations with CEO duality could settle on better and faster decision-makers so that those who divide the two positions may perform better [6,7].

Conversely, the stewardship theory contends that CEO duality builds up unambiguous and robust leadership. CEO ownership means CEO shareholding is the proportion of shares possessed by the CEO divided by total outstanding shares. At the bank level, the relationship of ownership structure (OS) and bank performance may differ because it depends on region, data sample composition, and economic context. Numerous financial analysts have seen that ownership structure is a vital governance tool, representing investors' capacity and care to adjust the directors' preferences to manage and observe their banks' transactions [8]. Furthermore, Caprio, Laeven, and Levine [9] noted that the ownership structure is a governance framework that helps investors to practice successful control. The board of director's management function is broadly recognized. The board is an important internal governance structure [10] to discipline executives in the decision-making practice [11]. Therefore, the board's monitoring role for top executives depends on the independent director's contribution to the board [12]. A more prominent representation of independent directors in the boardroom shows that the board might be opposed to top management's decision-making impact and limit them from abusing their power. Besides this background, CG changes worldwide have focused on reinforcing the board's observing function by guaranteeing that the boards are comprised of independent directors. CG assists in lessening the agency theory issue that diverts an organization's constant growth prospects.

RQ1: How do board diversity and moderating variables affect commercial banks' performance with different ownership types?

This research contributes to the current literature review in different directions. First, we give new knowledge on the contribution of female executives to the Chinese banking sector by researching the placement of female executives on a bank's board using an independent director as a moderating variable. This research finding suggests that board gender diversity change to an advanced level is a precise step; however, having female directors doesn't significantly impact bank financial performance. Next, we explain that independent directors are crucial in upgrading female executives' contribution to higher bank financial performance. The third contribution is that we found another dynamic and vital methodology of ownership structure by objective, which improves the governance quality inside Chinese CBs. The fourth contribution is that we examine a unique, coordinated, and multidisciplinary assessment approach of the ownership structure in Chinese CBs, which was invited for an extensive amendment of the principle of CG and included various perspectives and information. The investigation fills the literature review gap by tending to the issue of corporate governance on the performance of banks' across countries. Agency theory is discussed about to clarify the relation between corporate governance structure and performance. This examination can be considered one of the early investigations, investigating the relationship between corporate governance and bank efficiency from an emerging economy perspective. This work is also the first to investigate independent directors' moderating role in the relationship between corporate governance and bank performance by using Chinese data. 
The continuation of this research is coordinated as follows. Overviews of relevant literature and hypotheses development are given in Section 2. Section 3 portrays the research sample, variables, and the research model used in this study. The result and discussion are stated in Section 4 . Section 5 concludes this research.

\section{Literature and Hypothesis Development}

\subsection{Gender Diversity and Bank Performance}

Many prior studies are investigating the relationship between female directors and corporate performance. Still, most examinations have concentrated on organization financial performance, using different measurement variables to analyze the relationship between board gender diversity and financial performance. Vähämaa \&Baselga [13] suggest that banks with a higher proportion of female executives tend to have lower Z-scores than male-led organizations. However, female-led organizations are more profitable. The results from past investigations have to stay uncertain. Gender diversity is the central part of board diversity that is nowadays extensively examined. Females in terms of personality differ from men in correspondence style, educational background, professional experience, and skill [14], which will add to more extensive perception in organizations' decision-making. Additionally, females are more kind-hearted, less power aligned and less risk-taking than male executives [15]. Females are more dedicated [2], steadier [16], and less personally oriented [14,17,18]. Ali [19] shows that board diversity positively affects bank performance. Females are dominant in human relations, which helps organizations hold and extend human resources (HR)and improve relations with investors, customers, and different stakeholders [20]. This gender diversity adds to the long-term affiliation between organization employees, customers, and stakeholders that prompt better organization growth. Most experimental results revealed a positive relationship between board gender diversity and bank performance; for example, Campbell, Krishnan, and Nguyen [21-23]. Jurkus [24] showed a mixed relationship between gender diversity and corporate performance; Lee and James [25] indicated a negative relationship. Still, Mohan and Chen [26] showed no relationship. This paper recommends that board gender diversity enhances bank performance in Chinese CBs because female directors benefit banks that can observe their board of directors $[27,28]$. Therefore, considering the performance of Chinese CBs, we submit the following hypothesis:

Hypothesis 1 (H1). Comparing male and female directors onbank boards, having female directors improves bank performance.

\subsection{CEO Duality and Bank Performance}

The most questionable topic in CG literature is the board governance framework. The persons who advocate combining and separating the functions of CEO/Chairman both have their imaginary justifications, although the expressions that state combining or separating the $\mathrm{CEO} /$ chair are in some cases confusing. Some mention this as CEO duality and non-duality [5,29]. Brickley [30] refers to this as a unitary and dual leadership framework. Gupta [31] found that CEO education and CEO duality have a positive and significant effect on organization performance. This research describes the combination and separation of these two functions as CEO duality and non-duality. Stewardship scholars contend that executives are naturally reliable and good guardians of organization assets [32,33]. They trust CEO duality that could advance combined and strong management with a vivid idea of the strategic track. The CEO knows about the business and market condition and realizes how to operate the organization; integrating these two functions can help make sensible and ideal decisions [30]. Therefore, CEO duality positively affects the bank's financial performance, and it is here postulated that:

Hypothesis 2 (H2). CEO duality increases the financial performance of the banks. 


\subsection{CEO Shareholding and Bank Performance}

Featuring the CEO Shareholder in the agency theory background has indicated mixed results [34-37]. By involving this paper theme, Bhagat and Blair [38] didn't identify any proof to justify the correlation between CEO ownership and corporate performance. Likewise, [39] Dhillon and Rossetto indicated that the personal advantages beyond CEO ownership get an inverse effect on his desire to share confidential data with the top executives, minimizing control and impacting his independence. To motivate and convey financial reports to the top management, the CEO should ideally perform reconsideration with low observation strength when the CEO's ownership is weak or exploits several private advantages. In fact [40], Iqbal and Strobl found a correlation between large bank governance and structure risk from 2005 to 2010 in US banks. They indicated that banks with influential investors and governance base-board were related to higher structure risk degrees. Fahlenbrach argues [41] that there may be a subprime financial crisis when the bank director's rewards are continually ranged with its investor's benefits, as banks are initiating to perform better. Those banks' performances are higher, providing higher remuneration to CEOs than those that provide less remuneration to CEOs. The CEO having most of the capital breaks out a wide range of control, and would thus be able to supervise in optics as opposed to an increase of the bank value. In this process, scholars have contended that this may prompt entrenchment, particularly in situations where directors get high control, boundless scope inside the organization, or excess independence to function in their benefits $[42,43]$.

Hypothesis $3 \mathbf{~ ( H 3 ) . ~ W h e n ~ t h e ~ C E O ~ i s ~ a l s o ~ a n ~ o w n e r ~ o f ~ t h e ~ b a n k , ~ b a n k ~ f i n a n c i a l ~ p e r f o r m a n c e ~}$ is increased.

\subsection{Moderating Effect of Independent Directors on Female Directors' Performance}

Inthisresearch, we use board gender diversity and independent directors' moderating effect that increase bank productivity based on the principal-agent theory's assumption. As per this theory, the director is the peak of the bank governance structure. Shareholders depend on the board members to present his/her 'voice' in a bank boardroom and control the opportunistic tendency of directors. Independent directors are the most crucial top management component that depend on top management discipline and decision-making practices [11,44,45]. Independent directors' show mixed relation with bank performance [46]. CG codes worldwide have given incredible attention to independent directors to manage their contribution to the board of directors.

Additionally, the principal-agent theory proposes that more impressive board diversity becomes valuable for decision-making and monitoring function. Female directors' higher contribution in corporate boardrooms contributes to the information, perception, and way of dealing with critical thinking, which upgrades the policy formulation, decision making [47], and monitoring function of a boardroom. Campbell and Mínguez-Vera [21] reported this condition. We contend that combining board gender diversity and female independent directors may improve bank performance. Female directors will balance the oversight function anticipated of the female independent directors and vice-versa. Therefore, we suggest that female directors boost bank efficiency when appointing females as an independent director. The selection of a female independent director infers a better observing process since the top executives might be better capable of opposing the top management's influence in their decision-making and limiting them from abusing their power. Due to their temperament, female directors may prove more important as independent directors; for example, they are more careful and diligent in tending to the problems, more delicate to transpose in the financial market, more kind and committed (for example, higher participation rate), harder-working, and less personally oriented than their male counterparts $[15,48,49]$.We accept that CG should comprise a range or mix of monitoring systems to be a powerful bank, every component supplementing and strengthening the other. This paper proposes that the relationship between gender diversity and 
bank efficiency be moderated by the independent director in a boardroom. The monitoring capacity of independent directors could upgrade the positive results of gender diversity. We anticipate that our investigation results will give a significant recommendation to the policymakers, which endeavor to increase female contribution roles in the corporate board to boost bank performance. Therefore, we propose the accompanying hypothesis:

Hypothesis 4 (H4). The impact of board gender diversity is positive and significantly affects bank financial performance when banks appoint female independent directors to the bank board.

\section{Methodology}

\subsection{Date and Sample Selection}

The sample data for this research comprises selected commercial banks (CBs) in China from 2008 to 2019. We selected the data sample beginning period of 2008 to capture corporate governance's impact after the crucial banking reforms in the region because of the 2008 world financial crisis. We collected research data from the CSMAR (China Stock Market \& Accounting Research) database. We picked only Chinese CBs with at least 10years of research data sample for the study to give a superior presentation of bank performance. The implementation of selection standards provided us a data sample of $17 \mathrm{CBs}$. We employed the generalized method of moments (GMM) regression model construct on 170 observations to identify the relationship of the variables. We established the data on gender diversity and independent directors individually by analyzing executives' profiles and the historic part of annual reports.

\subsection{Description of Variables}

In this study, we employed return on asset (ROA), as banks' financial performance use different researchers in corporate governance studies(e.g., [50-52]). ROA is determined as the proportion of net income divided by total assets. In [53], Hutchinson and Gul contend that financial ratios are desirable to share market proportions to examine the correlation between CG and performance because they better reflect the executives' unusual behavior. Regarding gender diversity, we measured gender diversity to estimate the contribution of female directors in the bank governance framework. We measured female board representation by the proportion of female directors on a board, following earlier studies $[27,54]$. CEO duality was estimated by a binary variable coded; " 1 " if the board's CEO and Chairman were the same person and 2 for a different one. The CEOs shareholding refers to the proportion of capital held by the CEOs. This proportion was determined by dividing the number of shares held by the CEOs by the total number of banks' shares, following earlier studies $[55,56]$. An independent director is a director who is not an employee of the corporation and, by the excellence of being liberated from any correlation with board members, is less obligated to the executives [57]. Independent director was calculated as the proportion of independent directors in bank boards. To control the confounding factors effect on the study, we considered a group of variables whose impacts have been found in past studies. Moreover, based on the data analysis results, the selected variables were further used to assess their control impact. A few variables identified with board diversity and bank performance were used in the study [58]. This research used the bank size and financial leverage of the bank as control variables. The bank's size was estimated as its total assets [59]. Bank size is alleged to be positively correlated with bank financial performance because banks are inclined to reduce cost and catch market share set a better level of activities. However, in this study, we estimated bank size by taking the natural logarithm of the total assets of banks. Leverage is a proportion of bank equity and obligation to invest its resources. Leverage is a speculation methodology of using borrowed cash - explicitly, using different financial tools or borrowed capital to expand a bank's returns. Financial leverage can likewise allude to the amount of obligation a bank uses to finance resources. Frequently, banks' financial leverage is anticipated to earn 
interest funds than their expenses. Debt also increases with financial leverage [60]. Several investigations have indicated proof that leverage affects corporate performance.

\section{Regression Model}

As indicated by Adams and Ferreira [27], the investigation of female directors and bank performance concerns endogeneity problems, as bank performance plays the role of a motivator for females to connect with the boards and the boards' inspiration to expand the contribution rate of female executives. In this situation, we used a two-step framework GMM to identify the possible endogeneity issue in our analysis. GMM is a robust panel estimation method that considers potential endogeneity arising from unseen heterogeneity and a significant correlation between board attributes and bank efficiency [61]. Next, we developed a second-order autocorrelation test to ensure whether the error terms are sequentially associated. In this specific circumstance, the error-terms can be first-order sequentially correlated; however, not in the second-order. We calculated the relationship utilizing a principal model as introduced in Equation (1).

$$
\operatorname{ROA}_{j t}=\beta_{0}+\beta_{1} \text { Gender }_{j t}+\beta_{2} \text { CEODuality }_{j t}+\beta_{3} \text { CEOShareholding }_{j t}+\beta_{4} \text { LVR }_{j t}+\beta_{5} \text { Bsize }_{j t}+\varphi_{t}\left(\text { Year }_{t}+\varepsilon_{j t}\right.
$$

where ROA is return on assets of $j$ th bank at time $t$ respectively. Gender shows the proportion of female directors on a board. CEO duality coded " 1 " for the same person and "2" for a different one. The shareholding of the CEO refers to the proportion of capital held by the CEO. The GMM analysis takes a corroborative instead of an exploratory methodology. It permits the control for potential confounding variables that could modify the relationship's direction and analyze the nature of the relationship.

LVR is leverage, the total bank debt/shareholder's equity. Bsize is bank size, the $\mathrm{N}$-logarithm of the total assets of banks. Ind is the number of independent directors in banks board. $e_{i t}=$ error-terms. Further, we studied the moderating impact of independent directors on deciding whether gender diversity on the bank's financial performance was better when independent female directors were selected to the Chinese CB boards. We calculated this impact by employing an interaction variable of independent directors and gender diversity. The model was also founded on GMM, as demonstrated in Equation (2). Also, placing the female directors on the board was important in improving Chinese CB performance by a greater representation of female directors. We consolidated the interaction variable with the accompanying GMM regression model.

$\operatorname{ROA}_{j t}=\beta_{0}+\beta_{1}$ Gender $_{j t} \times$ Ind $_{j t}+\beta_{2}$ CEODuality $_{j t}+\beta_{3}$ CEOShareholding $_{j t}+\beta_{4}$ LVR $_{j t}+\beta_{5}$ Bsize $_{j t}+\varphi_{t}\left(\right.$ Year $_{t}+\varepsilon_{j t}$

where $B_{1}$ is the parameter used to recognize whether a female independent director's appointment enhances the financial performance of Chinese CBs.

The descriptive statistics of all the variables used in this research are shown in Table 1. These statistics were calculated by using 170 sample observations. In this article, bank financial performance is considered as a response variable measured by ROA with some independent variables such as gender, CEO-duality, CEO-shareholding, and independent director as a moderating variable. As seen in Table 1 for the dependent variable, the ROA has a mean value of $44 \%$ with a standard deviation of 0.36 , respectively. Regarding gender diversity, estimated by the female board of directors, the CBs of China have a " 1 " female board member maximum. There are additionally the banks without female board members in the banks. We also noted that the boards of Chinese CBs are men-dominated; only $75 \%$ percent of the examined $\mathrm{CB}$ shad a minimum of one female member in a board. The mean value of CEO-duality of 1.93 indicates that most $C B s$ show that the $C E O$ and chairman of Chinese $\mathrm{CBs}$ are not the same person. The independent variable $\mathrm{CEO}$-shareholding mean value is $35 \%$, which shows the Chinese CBs are distinguished by higher (however changing) ownership concentration levels. It realized that the independent director's mean value is 5.48 with a standard deviation of 0.36 . According to the data sample, Chinese CBs 
have a maximum value of 8 and a minimum value of 2 independent directors. This means that a maximum of 8 and a minimum of 2 independent directors exist on a bank board.

Table 1. Descriptive statistic of variables.

\begin{tabular}{cccccccc}
\hline & ROA & GENDER & CEO-DUALITY & CEO-Shareholding & IND & LVR & BSIZE \\
\hline Mean & 0.44 & 0.75 & 1.93 & 0.35 & 5.48 & 15.55 & 6230.00 \\
Median & 0.37 & 1.00 & 2.00 & 0.30 & 6.00 & 15.19 & 3240.00 \\
Maximum & 1.00 & 1.00 & 2.00 & 1.00 & 8.00 & 28.31 & 2410.00 \\
Minimum & 0.01 & 0.00 & 1.00 & 0.00 & 2.00 & 10.75 & 1300.00 \\
Std. Dev. & 0.36 & 0.44 & 0.26 & 0.29 & 1.01 & 2.90 & 6300.00 \\
Kurtosis & 3.11 & 2.29 & 12.24 & 49.30 & 4.20 & 8.28 & 3.00 \\
Jarque-Bera & 0.31 & 40.16 & 923.64 & 170 & 17.49 & 287.33 & 34.39 \\
Observations & 170 & 170 & 170 & 170 & 170 & 170 \\
\hline
\end{tabular}

Note: Bsize in billion (RMB), IND = independent director, $\mathrm{LVR}=$ leverage, Bsize = bank size.

Table 2 exhibits the Pearson pairwise correlation coefficients of all the variables analyzed in this research. A correlation matrix also assists in indicating the existence of Multicollinearity among the descriptive variables. The correlation coefficient values between all the variables vary in the actual values from a lower of 0.01 to a higher of 0.61 . The highest value of the correlation coefficient between the two predictors was 0.41 , between IND and BSIZE, which is not problematic. As Kennedy [62] suggested, multicollinearity is the occurrence of high intercorrelations among two or more independent variables in a multiple regression model can be measured as a legitimate problem if the relationship between predictors increases 0.80 . As a consequence, the model doesn't experience serious multicollinearity.

Table 2. Correlation matrix.

\begin{tabular}{cccccccc}
\hline & ROA & GENDER & CEO-DUALITY & CEO-Shareholding & IND & LVR & BSIZE \\
\hline ROA & 1.00 & & & & & & \\
GENDER & 0.60 & 1.00 & & & & & \\
CEO-DUALITY & 0.53 & 0.16 & 1.00 & 1.00 & & \\
CEO-Shareholding & 0.58 & 0.02 & 0.06 & 0.08 & 1.00 & \\
IND & 0.61 & 0.09 & 0.22 & 0.06 & 0.30 & 1.00 \\
LVR & 0.42 & 0.02 & 0.01 & 0.13 & 0.16 & 0.41 & 1.00 \\
BSIZE & 0.52 & 0.20 & 0.02 & & & & \\
\hline
\end{tabular}

Note: The table exhibits pairwise relationships for the main variables employed in the experimental analysis.

\section{Result and Discussion}

This research used the GMM model to estimate the impact of board diversity and ownership on a bank's financial performance, considering independent directors' moderating role. The results are shown in Table 3. Concerning the GMM model analyzing the impact of gender diversity - for example, female representation in the bank board and the upper management-on ensuing performance, findings exhibit that gender diversity is significant and positively correlated with a bank's efficiency. The study's first hypotheses revealed that gender diversity in the bank's board is significant and positively impacts the bank's financial performance. The findings support assumption H1. From Model " $\mathrm{D}$ " in Table 3, we report that the significant positive impact of board gender diversity on ensuing performance is significant when performance is estimated as the return on assets (ROA) (Model " $\mathrm{D}$ ": $\beta_{1}=0.699$ and $p$-value $<1$ percent). These findings are consistent with earlier investigations managing the estimation of the correlation between female representation in boardrooms and performance in advanced economies $[3,13,63]$ and in rising economies $[64,65]$. Table 3 shows that duality positively affects commercial banks ${ }^{\prime}$ financial performance CBs $[31,66]$. This result confirms and supports the second hypothesis (H2) of the study, which means that a duality can run and administer the bank obviously 
and consistently to expand the bank's consequences. Some earlier studies recommended that non-duality might be acceptable in specific conditions; CEO duality might be best in others. Pham [67] found that distinctive board governance frameworks (CEO duality or non-duality) have their own expected advantages. The possible monitoring advantages of non-duality incorporate the partition of the governing body and controls. The potential expenses of non-duality incorporate information asymmetry, conflicting decisions, and additional payments to sustain two titles. The CEO knows more about the bank's business climate and has particular business issues and opportunities. Besides, the transfer of incomplete information between the CEO and chairperson in those banks with a non-duality framework weakens the bank's competitive framework in a unique business climate. In this way, the expected advantages and costs of various board governance frameworks for the bank should be weighed. Whether the prospective monitoring advantages of non-duality exceed the possible costs for keeping up such a framework, at that point, non-duality is best. In contrast, CEO duality is ideal the opposite way around. The results point out that CEO ownership is positively and significantly correlated with a bank's financial performance. In light of these results, the third hypothesis (H3), of the study is supported and accepted. These findings are consistent with Afriani and Aswan [68], who realized a positive connection between CEO shareholdings and financial performance. Similar studies like Rasli and Bhuiyan [69] recommend that CEO shareholding expands the potential for minority shareholder appropriation.

Table 3. Estimated results of female representation, CEO, and bank performance.

\begin{tabular}{|c|c|c|c|c|c|}
\hline Variables & & Model A & Model B & Model C & Model D \\
\hline \multirow[t]{2}{*}{ Control Variables } & LVR & $-0.252 * * *$ & $-0.253^{* * *}$ & $-0.257^{* * *}$ & $-0.286^{* * *}$ \\
\hline & Bsize & $0.415^{* * *}$ & $0.422^{* * *}$ & $0.423^{* * *}$ & $0.379^{* * *}$ \\
\hline \multirow[t]{3}{*}{ Independent Variables } & Gender & & 0.127 * & $0.128 * *$ & $0.699^{* * *}$ \\
\hline & Duality & & $0.193 * *$ & $0.189 * * *$ & $0.120 * *$ \\
\hline & CEO Shareholder & & $0.121^{* * *}$ & $0.122 *$ & $0.497 *$ \\
\hline Moderator & IND & & & $0.017^{* *}$ & $0.218^{* *}$ \\
\hline \multirow[t]{4}{*}{ Interaction Variables } & Gender* IND & & & & $0.898^{* * *}$ \\
\hline & $\mathrm{R}^{2}$ & 0.322 & 0.375 & 0.376 & 0.400 \\
\hline & $\Delta \mathrm{R}^{2}$ & 0.314 & 0.356 & 0.353 & 0.366 \\
\hline & $\mathrm{F}$ & 39.592 & 19.712 & 16.344 & 11.827 \\
\hline
\end{tabular}

Note: ${ }^{*}, * *{ }^{* * *}$ significant at the $10 \%, 5 \%$, and $1 \%$ levels, respectively.

Further, our findings propose that neither gender diversity nor independent directors alone are adequate to improve the financial performance of CBs. Nevertheless, when we introduce gender diversity and independent directors' interaction, we found that it improves bank financial performance. In fact, female directors' positive characteristics must be valuable to the bank when they are appointed as independent directors, suggesting that CBs can accomplish higher productivity when appointing female independent directors to the bank board. Our results on the moderating impact of independent directors also propose that consolidating female directors' positive characteristics with an independent director's managerial function grows bank productivity of CBs of China in the investigated sample data. In this case, bank boards are to practice independent thoughts and decisionmaking to monitor and advise the board of directors in Chinese CBs, and to exploit the diversity in management decision, work experience, and new ideas on complicated problems brought by female executives, improving bank financial performance. Similarly, female independent directors' impact on bank productivity is positive when incorporated with board gender diversity in the boardroom. The results suggest that female independent directors are viable observers in a boardroom, and their monitoring function should be expanded.

Bank size did show a significant positive relationship with financial performance, suggesting that small banks achieve market performance and large banks achieve business performance. Conversely, smaller banks can resolve their problems more quickly, and 
larger banks face larger issues. The control variable bank size indicates a significant positive relationship between ROA and bank market esteem. The results demonstrate that a sizeable bank improves ROA and improves its reasonable worth. Size is significant because large banks are in an ideal situation to increase their performance by guaranteeing better usage of their considerable assets $[70,71]$. Subsequently, financial investors favor large banks that expand their market worth. The relationship between bank size and their performance is positive. A few studies consider the bank size effect non-linear, with productivity rising with CB size and contracting because of technical factors, among different reasons [72]. Discussing the examinations of Haniffa and Cooke [73], results were not consistent with the proposed studies and conclusion. While the relationship of the control variable leverage to bank performance was insignificant, a high level of leverage nonetheless increases the risk of insolvency. Present literature clarifies that when leverage increases, interest cost also increases, leading to a decrease in a bank's productivity [74].

Therefore, the relationship between leverage and bank market worth is negative and insignificant. This result supports the study by Rasli [69], who discovered that investors check a bank's capacity to realize the degree of leverage that suits them. Table 3 exhibits the consequences of GMM regression analysis. The GMM was accomplished to assess how well the bank's performance (ROA) can be described by knowing financial performance banks' value. In this model, the specification of the following variables (gender, CEO duality, CEO shareholding, independent director (moderator), board size, and leverage) exposed the ability to anticipate the bank financial performance ROA. A particular R2 value of 0.40 in Model " $\mathrm{D}$ " indicates that $40 \%$ of the observed inconstancy in ROA can be explained by the differences in variables to be specific gender, CEO duality, CEO shareholding, independent director, the board size, and leverage. The remaining $60 \%$ is not described, which implies that the remaining $60 \%$ of the ROA change is identified with different variables not portrayed in this model.

Table 4 indicates that these research variables are stationary, as shown by Prob (F-statistic), which is less than 0.05. These show that the data of this study is stationary and cannot violate the assumptions of data stationery.

Table 4. Augmented Dickey-Fuller Tests.

\begin{tabular}{|c|c|c|c|}
\hline \multicolumn{4}{|c|}{ Null Hypothesis: ROA Has a Unit Root } \\
\hline \multicolumn{4}{|c|}{ Exogenous: Constantz } \\
\hline \multicolumn{4}{|c|}{ Lag Length: 4 (Automatic-Based on AIC, Maxlag = 5) } \\
\hline & & $t$-Statistic & Prob.* \\
\hline \multicolumn{2}{|c|}{ Augmented Dickey-Fuller test statistic } & -4.544248 & 0.0000 \\
\hline \multirow[t]{3}{*}{ Test critical values: } & $1 \%$ level & -4.352934 & \\
\hline & $5 \%$ level & -3.786301 & \\
\hline & $10 \%$ level & -3.564562 & \\
\hline
\end{tabular}

\section{Conclusions}

Recently, board gender diversity has become a significant agenda in CG reforms worldwide. The point of conflict is the object of placing female directors on bank boards. When female directors are appointed to a bank board entirely due to cultural pressure or administrative requirement rather than merit-based appointments, it might negatively impact bank performance. Considering these challenges, we examined the impact of female directors on the bank's financial performance. We further explored whether the placing of female directors as independent directors impacts bank financial performance. Our moderating effect investigation results give an innovative dimension to female independent directors' governance role in Chinese CBs. Specifically, it is significant for the banking managers and strategy makers to take note that the goal of increasing female contribution in bank boards to increase diversity and monitoring function of the boardrooms and 
eventually influence performance positively can be accomplished when there is a higher independent female director contribution in bank boards. This research found that merely positioning female directors on bank boards doesn't yield a positive impact. However, it is the correct placing of female directors as independent directors and the female independent director's contribution to the board that is crucial to understand the significant potential performance impact of their commitments to the banks' top management. Finally, we propose that individual banks and banking managers should identify a massive pool of well-qualified, experienced, and capable female experts, and train them for future appointments as independent directors in China's banking institutions.

We found that CEO duality [31,75] had a positive and significant impact on bank financial performance. The focus of decision-making with the sole individual is excellent for the strength of the Chinese CBs by increasing business decisions and diminishing the delay in its accomplishment. On the other hand, Pucheta-Martínez and Yang [71,76] reflected that CEO duality can run and supervise the bank obviously and consistently so the bank performance can be expanded to bring shareholders advantages. Our results are consistent with this [31-75]. The outcomes show that there is a positive relationship between CEO-shareholding with bank financial performance. These outcomes affirm some past investigations; for example, $[68,77]$ found that bank performance is positive affected by ownership structure. The current research recognizes that the bank size improves its financial performance, while leverage negatively relates to the bank's financial performance.

\section{Limitations and Future Research Directions}

Throughout this investigation, a few ideas and potential investigation areas have been recognized. The motivation behind this part is to provide a source of motivation for further analysts. In this way, the followings are the recommendations for future research.

There are more than 17 scheduled CBs in China, but this investigation chose just 17banks as a research sample. Numerous CG variables are accessible; however, this research considers just five variables. Only financial performance was considered in this research; in the future non-financial performance should also be considered. Secondary data was used in this study; primary data should be considered in future investigations. Just 10 years of data were obtained for the inquiry. Future investigations should increase the study period by more than 10 years, and take data from other industries beyond simply banking industries.

We accept that GMM analysis is a significant device that takes an affirmative rather than an exploratory approach and controls for potential confounding variables that could modify the direction of the relationships, which permitted the examination of the indepth nature of the relationship. When these banks' data are taken on a quarterly basis instead of annual, and the lag effects are included in the data analysis, they will give more robust results.

Author Contributions: All authors contributed equally. All authors have read and agreed to the published version of the manuscript.

Funding: This paper is funded by the National Social Science Fund of China (Grant No. 16BGL094), Science and Technology, Guangzhou Province, China (Grant No. 2017A040403072), The Innovation Team Project of Guangzhou, China (Grant No. 201831799), and Foundation of Humanities and Social Science Research Program, Ministry of Education (Grant No. 15YJCZH225).

Institutional Review Board Statement: The Research Ethics Committee of Guangzhou University and University Approved This Study, And It Was Secondary Data- Base Research.

Informed Consent Statement: Not applicable.

Data Availability Statement: The data will be available on request.

Conflicts of Interest: The authors declare that they have no competing interests. 


\section{References}

1. Potter, M. Women on Boards of the Top 100 Companies in Northern Ireland; Northern Ireland Assembly: Belfast, UK, 2015.

2. Ramly, Z.; Chan, S.-G.; Mustapha, M.Z.; Sapiei, N.S. Women on boards and bank efficiency in ASEAN-5: The moderating role of the independent directors. Rev. Manag. Sci. 2017, 11, 225-250. [CrossRef]

3. Naseem, M.A.; Lin, J.; Rehman, R.U.; Ahmad, M.I.; Ali, R. Does capital structure mediate the link between CEO characteristics and firm performance? Manag. Decis. 2020, 58, 164-181. [CrossRef]

4. Aggarwal, R.; Jindal, V.; Seth, R. Board diversity and firm performance: The role of business group affiliation. Int. Bus. Rev. 2019, 28, 101600. [CrossRef]

5. Finkelstein, S.; D'aveni, R.A. CEO duality as a double-edged sword: How boards of directors balance entrenchment avoidance and unity of command. Acad. Manag. J. 1994, 37, 1079-1108.

6. Rechner, P.L.; Dalton, D.R. CEO duality and organizational performance: A longitudinal analysis. Strateg. Manag. J. 1991, 12, 155-160. [CrossRef]

7. Jiang, F.; Kim, K.A. Corporate governance in China: A survey. Rev. Financ. 2020, 24, 733-772. [CrossRef]

8. Nam, S.-W.; Nam, I.C. Corporate Governance in Asia: Recent Evidence from Indonesia, Republic of Korea, Malaysia, and Thailand; Asian Development Bank Institute: Tokyo, Janpan, 2004.

9. Caprio, G.; Laeven, L.; Levine, R. Governance and bank valuation. J. Financ. Intermediat. 2007, 16, 584-617. [CrossRef]

10. Ahmed, A.S.; Duellman, S. Accounting conservatism and board of director characteristics: An empirical analysis. J. Account. Econ. 2007, 43, 411-437. [CrossRef]

11. Kosnik, R.D. Effects of board demography and directors' incentives on corporate greenmail decisions. Acad. Manag. J. 1990, 33, 129-150.

12. Adams, R.B.; Hermalin, B.E.; Weisbach, M.S. The role of boards of directors in corporate governance: A conceptual framework and survey. J. Econ. Lit. 2010, 48, 58-107. [CrossRef]

13. Vähämaa, E.; Baselga-Pascual, L. Female Leadership and Bank Performance in Latin America. Available online: https://papers. ssrn.com/sol3/papers.cfm?abstract_id=3581714 (accessed on 18 May 2020).

14. Liao, L.; Luo, L.; Tang, Q. Gender diversity, board independence, environmental committee and greenhouse gas disclosure. Br. Account. Rev. 2015, 47, 409-424. [CrossRef]

15. Adams, R.B.; Funk, P. Beyond the glass ceiling: Does gender matter? Manag. Sci. 2012, 58, 219-235. [CrossRef]

16. Nielsen, S.; Huse, M. The contribution of women on boards of directors: Going beyond the surface. Corp. Gov. Int. Rev. 2010, 18, 136-148. [CrossRef]

17. Carter, D.A.; Simkins, B.J.; Simpson, W.G. Corporate governance, board diversity, and firm value. Financ. Rev. 2003, 38, 33-53. [CrossRef]

18. Cox, T.H.; Blake, S. Managing cultural diversity: Implications for organizational competitiveness. Acad. Manag. Perspect. 1991, 5, 45-56. [CrossRef]

19. Ali, F.; Wang, M.; Jebran, K.; Ali, S.T. Board diversity and firm efficiency: Evidence from China. Corp. Gov. Int. J. Bus. Soc. 2021. ahead-of-print. [CrossRef]

20. Lee, J.S.; Lan, L.L.; Rowley, C. Why might females say no to corporate board positions? The Asia Pacific in comparison. Asia Pac. Bus. Rev. 2014, 20, 513-522. [CrossRef]

21. Campbell, K.; Mínguez-Vera, A. Gender diversity in the boardroom and firm financial performance. J. Bus. Ethics. 2008, 83, 435-451. [CrossRef]

22. Krishnan, H.A.; Park, D. A few good women-On top management teams. J. Bus. Res. 2005, 58, 1712-1720. [CrossRef]

23. Nguyen, T.; Locke, S.; Reddy, K. Does boardroom gender diversity matter? Evidence from a transitional economy. Int. Rev. Econ. Financ. 2015, 37, 184-202. [CrossRef]

24. Jurkus, A.F.; Park, J.C.; Woodard, L.S. Women in top management and agency costs. J. Bus. Res. 2011, 64, 180-186. [CrossRef]

25. Lee, P.M.; James, E.H. She'-e-os: Gender effects and investor reactions to the announcements of top executive appointments. Strateg. Manag. J. 2007, 28, 227-241. [CrossRef]

26. Mohan, N.J.; Chen, C.R. Are IPOs priced differently based upon gender? J. Behav. Financ. 2004, 5, 57-65. [CrossRef]

27. Belaounia, S.; Tao, R.; Zhao, H. Gender equality's impact on female directors' efficacy: A multi-country study. Int. Bus. Rev. 2020, 29, 101737. [CrossRef]

28. Gul, F.A.; Srinidhi, B.; Ng, A.C. Does board gender diversity improve the informativeness of stock prices? J. Account. Econ. 2011, 51, 314-338. [CrossRef]

29. Baliga, B.R.; Moyer, R.C.; Rao, R.S. CEO duality and firm performance: What's the fuss? Strateg. Manag. J. 1996, 17, 41-53. [CrossRef]

30. Brickley, J.A.; Coles, J.L.; Jarrell, G. Leadership structure: Separating the CEO and chairman of the board. J. Corp. Financ. 1997, 3, 189-220. [CrossRef]

31. Gupta, N.; Mahakud, J. CEO characteristics and bank performance: Evidence from India. Manag. Audit. J. 2020, 35, 1057-1093. [CrossRef]

32. Donaldson, L. The ethereal hand: Organizational economics and management theory. Acad. Manag. Rev. 1990, 15, 369-381. [CrossRef] 
33. Donaldson, L.; Davis, J.H. Boards and company performance-research challenges the conventional wisdom. Corp. Gov. Values Ethics Leadersh. 1994, 2, 151-160. [CrossRef]

34. Veprauskaite, E.; Adams, M. Do powerful chief executives influence the financial performance of UK firms? Br. Account. Rev. 2013, 45, 229-241. [CrossRef]

35. Luo, Y. CEO power, ownership structure and pay performance in Chinese banking. J. Econ. Bus. 2015, 82, 3-16. [CrossRef]

36. Gupta, V.K.; Han, S.; Nanda, V.; Silveri, S. When crisis knocks, call a powerful CEO (or not): Investigating the contingent link between CEO power and firm performance during industry turmoil. Group Organ. Manag. 2018, 43, 971-998. [CrossRef]

37. Saidu, S. CEO characteristics and firm performance: Focus on origin, education and ownership. J. Glob. Entrep. Res. 2019, 9, 29. [CrossRef]

38. Bhagat, S.; Black, B.; Blair, M. Relational investing and firm performance. J. Financ. Res. 2004, 27, 1-30. [CrossRef]

39. Dhillon, A.; Rossetto, S. Ownership structure, voting, and risk. Rev. Financ. Stud. 2015, 28, 521-560. [CrossRef]

40. Iqbal, J.; Strobl, S.; Vähämaa, S. Corporate governance and the systemic risk of financial institutions. J. Econ. Bus. 2015, 82, 42-61. [CrossRef]

41. Fahlenbrach, R.; Stulz, R.M. Bank CEO incentives and the credit crisis. J. Financ. Econ. 2011, 99, 11-26. [CrossRef]

42. Morck, R.; Shleifer, A.; Vishny, R.W. Management Ownership and Corporate Performance: An Empirical Analysis; National Bureau of Economic Research: Oxford, UK, 1986.

43. Li, J.; Mangena, M.; Pike, R. The effect of audit committee characteristics on intellectual capital disclosure. Br. Account. Rev. 2012, 44, 98-110. [CrossRef]

44. Black, B.S.; Jang, H.; Kim, W. Does corporate governance predict firms' market values? Evidence from Korea. J. Law Econ. Organ. 2006, 22, 366-413. [CrossRef]

45. Chijoke-Mgbame, A.M.; Boateng, A.; Mgbame, C.O. Board gender diversity, audit committee and financial performance: Evidence from Nigeria. Accounting Forum. 2020, 44, 262-286. [CrossRef]

46. Aslam, E.; Haron, R. Does corporate governance affect the performance of Islamic banks? New insight into Islamic countries. Corp. Gov. Int. J. Bus. Soc. 2020, 20, 1073-1109.

47. Westphal, J.D.; Milton, L.P. How experience and network ties affect the influence of demographic minorities on corporate boards. Adm. Sci. Q. 2000, 45, 366-398. [CrossRef]

48. Hillman, A.J.; Cannella, A.A., Jr.; Harris, I.C. Women and racial minorities in the boardroom: How do directors differ? J. Manag. 2002, 28, 747-763. [CrossRef]

49. Darmadi, S. Do women in top management affect firm performance? Evidence from Indonesia. Corp. Gov. Int. J. Bus. Soc. 2013, 13, 288-304. [CrossRef]

50. Galeotti, M. Governo Dell'azienda e Indicatori di Performance; G. Giappichelli: Bologna, Italy, 2006.

51. Easterwood, J.C.; İnce, Ö.Ş.; Raheja, C.G. The evolution of boards and CEOs following performance declines. J. Corp. Financ. 2012, 18,727-744. [CrossRef]

52. Terjesen, S.; Couto, E.B.; Francisco, P.M. Does the presence of independent and female directors impact firm performance? A multi-country study of board diversity. J. Manag. Gov. 2016, 20, 447-483. [CrossRef]

53. Hutchinson, M.; Gul, F.A. Investment opportunity set, corporate governance practices and firm performance. J. Corp. Financ. 2004, 10, 595-614. [CrossRef]

54. Ahern, K.R.; Dittmar, A.K. The changing of the boards: The impact on firm valuation of mandated female board representation. Q. J. Econ. 2012, 127, 137-197. [CrossRef]

55. Al-Hawary, S. The Effect of banks governance on banking performance of the Jordanian commercial banks: Tobin's Q Model" An Applied Study. Int. Res. J. Financ. Econ. 2011, 71, 34-47.

56. Kim, P.K.; Rasiah, D.; Tasnim, R.B. A review of corporate governance: Ownership structure of domestic-owned banks in term of government connected ownership, and foreign ownership of commercial banks in Malaysia. J. Organ. Manag. Stud. 2012, 2012, 1. [CrossRef]

57. Hermalin, B.E.; Weisbach, M.S. Boards of Directors as an Endogenously Determined Institution: A Survey of the Economic Literature; National Bureau of Economic Research: New York NY, USA, 2001.

58. García-Meca, E.; García-Sánchez, I.M.; Martínez-Ferrero, J. Board diversity and its effects on bank performance: An international analysis. J. Bank. Financ. 2015, 53, 202-214. [CrossRef]

59. Wang, H.; Qian, C. Corporate philanthropy and corporate financial performance: The roles of stakeholder response and political access. Acad. Manag. J. 2011, 54, 1159-1181. [CrossRef]

60. Enekwe, C.I.; Agu, C.I.; Eziedo, K. The effect of financial leverage on financial performance: Evidence of quoted pharmaceutical companies in Nigeria. J. Econ. Financ. 2014, 5, 17-25.

61. Roodman, D. How to do xtabond2: An introduction to difference and system GMM in Stata. Stata J. 2009, 9, 86-136. [CrossRef]

62. Kennedy, P. A Guide to Econometrics; Kennedy2A Guide to Econometrics 1985; MITPress: Cambridge, MA, USA, 1985.

63. Hoogendoorn, S.; Oosterbeek, H.; Van Praag, M. The impact of gender diversity on the performance of business teams: Evidence from a field experiment. Manag. Sci. 2013, 59, 1514-1528. [CrossRef]

64. Mahadeo, J.D.; Soobaroyen, T.; Hanuman, V.O. Board composition and financial performance: Uncovering the effects of diversity in an emerging economy. J. Bus. Ethics. 2012, 105, 375-388. [CrossRef] 
65. Ararat, M.; Aksu, M.; Cetin, A.T. How board diversity affects firm performance in emerging markets: Evidence on channels in controlled firms. Corp. Gov. Int. Rev. 2015, 23, 83-103. [CrossRef]

66. Kılıç, M.; Kuzey, C. The effect of board gender diversity on firm performance: Evidence from Turkey. Gend. Manag. Int. J. 2016, 31, 434-455. [CrossRef]

67. Handa, R. Does corporate governance affect financial performance: A study of select Indian banks. Asian Econ. Financ. Rev. 2018, 8,478 .

68. Pham, D.; Pham, Q. The impact of CEO duality on firm performance: Examining the life-cycle theory in Vietnam. Accounting 2020, 6, 737-747. [CrossRef]

69. Afriani, Y.; Laba, A.R.; Aswan, A. The Effect of Managerial Ownership, Financial Performance, Corporate Competition on Stock Prices with Capital Structure as the Intervening Variable in the Coal Mining Companies Listed on the Indonesia Stock Exchange. Hasanuddin J. Bus. Strategy 2020, 2, 24-33. [CrossRef]

70. Rasli, S.; Kassim, A.A.M.; Bhuiyan, A.B. Shariah Governance Characteristics and Risk-Taking of Local and Foreign Islamic Banks in Malaysia: A Conceptual Model. J. Account. Financ. Emerg. Econ. 2020, 6, 441-451. [CrossRef]

71. Manduku, G.O.; Mulwa, J.M.; Omolo, J.W.; Lari, L.R.A. Influence of Corporate Governance Practices on Financial Distress of Firms Listed at the Nairobi Securities Exchange, Kenya; Rongo University: Rongo, Kenya, 2020.

72. Pucheta-Martínez, M.C.; Gallego-Álvarez, I. Do board characteristics drive firm performance? An international perspective. Rev. Manag. Sci. 2020, 14, 1251-1297. [CrossRef]

73. Haniffa, R.M.; Cooke, T.E. Culture, corporate governance and disclosure in Malaysian corporations. Abacus 2002, 38, 317-349. [CrossRef]

74. Mukras, M.S. Financial Leverage and Performance of Listed Firms in a Frontier Market: Panel Evidence from Kenya; Maseno University: Maseno, Kenya, 2015.

75. Peni, E. CEO and chairperson characteristics and firm performance. J. Manag. Gov. 2014, 18, 185-205. [CrossRef]

76. Yang, T.; Zhao, S. CEO duality and firm performance: Evidence from an exogenous shock to the competitive environment. J. Bank. Financ. 2014, 49, 534-552. [CrossRef]

77. Asadi, A.; Pahlevan, M. The relationship between ownership structure and firms' performance in Tehran stock exchange. J. Insur. Financ. Manag. 2016, 1, 62-76. 